JURNAL SAINS dan INOVASI PERIKANAN
Journal of Fishery Science and Innovation
e-ISSN: 2502-3276
Vol. 3, No.1, 9-13, Januari 2019
http://ois.uho.ac.id/index.php/JSIPi

\title{
Kelayakan Usaha Alat Tangkap Ikan Pelagis Besar di Kabupaten Wakatobi
}

\section{Financial Feasibility of Fishing The Large Pelagic Fish in Wakatobi Regency}

\author{
Sri Eka Agusliana ${ }^{1 *)}$, La Anadi ${ }^{2)}$, Naslina Alimina ${ }^{3)}$ \\ ${ }^{1)}$ Program Studi Ilmu Perikanan Pascasarjana Univesitas Halu Oleo, Kendari, Indonesia \\ 2) Fakultas Perikanan dan Ilmu Kelautan Universitas Halu Oleo, Kendari, Indonesia \\ ${ }^{3)}$ Fakultas Perikanan dan Ilmu Kelautan Universitas Halu Oleo, Kendari, Indonesia \\ Corresponding author ${ }^{*}$ ): aguslianasrieka@gmail.com
}

\begin{abstract}
Wakatobi is a region with abundant fishery resources. Fisheries and marine resources in the area are used as a source of livelihood by 26,174 fishermen or around 27.61 percent of the population. Overall, the large pelagic fishing business in Wakatobi is currently quite developed as a community fishery with the dominant species have being caught are frigate mackerel (Auxis thazard), skipjack tuna (Katsuwonus pelamis), and yellow fin tuna (Thunnus albacares). The fishing gear used in this research was trolling line and hand line operated by 1 to 2 fishermen per boat unit. The purpose of this study was to determine the financial feasibility of trolling and hand line of activity for taking hold of large pelagic fish in Wakatobi. This study was conducted in August to October 2018. Survey method was used in this research. The analysis used in this study was financial analysis against fishing gear such as business income analysis $(\pi)$, BEP (Break Even Point) analysis, and NPV (Net Present Value) analysis. Based on the results of analysis, the feasibility of trolling line and hand line in Wakatobi is able to be appropriate to make it developed as all requirements for financial feasibility criteria have been fulfilled.
\end{abstract}

Keywords : financial feasibility, fishing gear, large pelagic fish, Wakatobi

\begin{abstract}
ABSTRAK
Wakatobi merupakan wilayah dengan sumberdaya perikanan yang cukup melimpah. Sumberdaya perikanan dan kelautan di wilayah tersebut dimanfaatkan sebagai sumber mata pencaharian oleh 26.174 orang nelayan atau sekitar 27,61 persen dari jumlah populasi. Secara keseluruhan, usaha penangkapan ikan pelagis besar di Wakatobi saat ini cukup berkembang sebagai perikanan rakyat dengan jenis-jenis ikan yang dominan tertangkap adalah jenis ikan tongkol (Auxis thazard), cakalang (Katsuwonus pelamis), dan tuna sirip kuning (Thunnus albacares). Alat tangkap yang digunakan adalah pancing tonda dan pancing ulur yang dioperasikan oleh 1 sampai 2 orang nelayan per unit perahu. Tujuan penelitian ini adalah mengetahui kelayakan alat tangkap pancing tonda dan pancing ulur untuk kegiatan penangkapan ikan pelagis besar di Wakatobi. Penelitian ini dilakukan pada Bulan Agustus sampai Oktober 2018. Metode yang digunakan adalah metode survei. Analisis yang digunakan adalah analisis finansial terhadap alat tangkap yang terdiri atas analisis pendapatan usaha $(\pi)$, analisis BEP(break even point), dan analisis NPV (net present value). Berdasarkan hasil analisis, bahwa kelayakan usaha dari alat tangkap pancing tonda dan pancing ulur di Wakatobi dikatakan layak untuk dikembangkan karena semua syarat kriteria kelayakan usaha dapat dipenuhi.
\end{abstract}

Kata kunci : kelayakan usaha, alat tangkap, ikan pelagis besar, Wakatobi

DOI: http://dx.doi.org/10.33772/jspi.v3n1. 
10 Sri Eka Aguslinaet al.

JURNAL SAINS dan INOVASI PERIKANAN / Journal of Fishery Science and Innovation

Vol. 3, No. 1, 9-13, Januari 2019

\section{PENDAHULUAN}

Kabupaten Wakatobi sebagai salah satu wilayah dengan luas $\pm 19.200 \mathrm{~km}^{2}$ didominasi oleh perairan laut $\left( \pm 18.337 \mathrm{~km}^{2}\right)$ danberhubungan langsung dengan Laut Banda di bagian timur dan utara serta Laut Flores di bagian barat dan selatan (Bappeda Kabupaten Wakatobi, 2016). Daerah ini memiliki sumberdaya kelautan dan perikanan yang melimpah, terutama di pesisir dan laut yang belum dimaksimalkan pemanfaatannya.

Sumberdaya perikanan dan kelautan di Kabupaten Wakatobi dimanfaatkan sebagai sumber mata pencaharian oleh sekitar 26.174 orang nelayan atau sekitar $27,61 \%$ dari jumlah populasi 94.789 penduduk di Kabupaten Wakatobi dengan jumlah RTP sekitar 4.354 (DKP Wakatobi, 2016). Hal ini sangat mungkin terjadi, mengingat area tangkap nelayan di Kabupaten Wakatobi merupakan bagian dari Wilayah Pengelolaan Perikanan Laut Banda dan Teluk Tolo (WPPNRI 714), dengan potensi perikanan sebesar 431.069 ton/tahun (KKP, 2016).

Usaha penangkapan ikan pelagis besar di Kabupaten Wakatobi saat ini cukup berkembang dan bersifat perikanan rakyat. Ikan pelagis besar yang dominan ditangkap oleh nelayan adalah tongkol, cakalang, dan tuna. Alat tangkap yang digunakan adalah pancing tonda dan pancing ulur yang dioperasikan oleh 1 sampai 2 orang nelayan per unit perahu. Alimina et al. (2016) menyatakan bahwa pancing tonda merupakan perikanan tuna skala kecil.

Potensi perikanan lestari di Kabupaten Wakatobi adalah 81.000 ton/tahun dan baru termanfaatkan sekitar 18.855,3 ton/tahun atau sebesar 23,37\% (DKP Wakatobi, 2016). Berdasarkan data tersebut, salah satu permasalahan yang terjadi pada pengembangan perikanan tangkap di suatu wilayah adalah "over capacity" (faktor produksi lebih banyak dibanding potensi sumberdaya yang dimanfaatkan) dan sebaliknya "under capacity". Penentuan tingkat pemanfaatan ini sangat terkait dengan peralatan pendukung perikanan tangkap yang memenuhi syarat kelayakan usaha untuk dikembangkan.Berdasarkan uraian di atas maka tujuan dari penelitian ini adalah mengetahui kelayakan usaha alat tangkap ikan pelagis besar yang digunakan di Kabupaten Wakatobi.

\section{METODE PENELITIAN}

Penelitian ini dilakukan di Kabupaten Waaktobi pada Bulan Agustus sampai Oktober 2018. Jenis ikan pelagis besar yang dimaksud dalam penelitian ini adalah tiga jenis ikan pelagis besar yang dominan tertangkap di Kabupaten Wakatobi yaitu ikan tongkol (Auxisthazard), ikan tuna (Thunnus albacares) dan ikan cakalang (Katsuwonus pelamis) dengan alat tangkap pancing tonda dan pancing ulur.

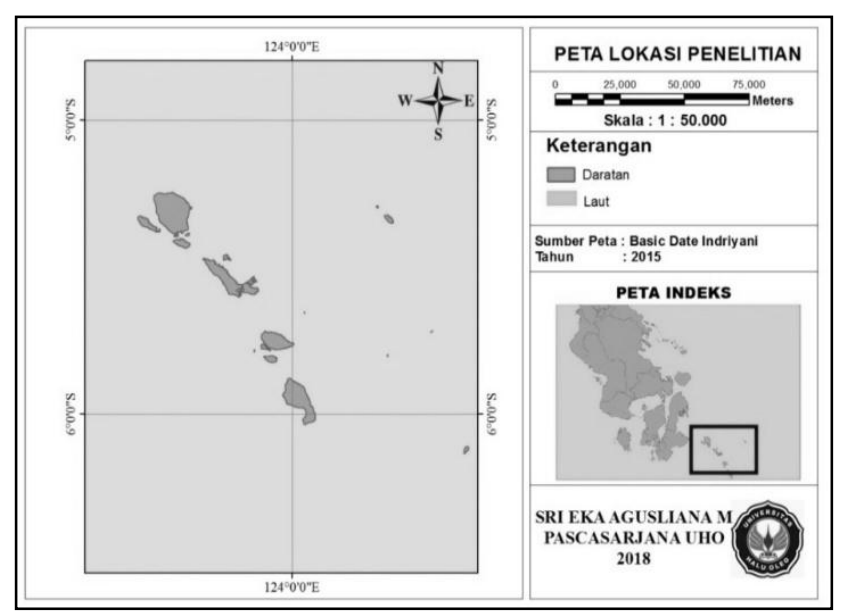

Gambar 1. Lokasi penelitian

Data yang dikumpulkan adalah data primer dan data sekunder. Data primer yang dikumpulkan disesuaikan dengan masing-masing tujuan penelitian (Tabel 1).

Tabel 1. Data-data yang dikumpulkan pada penelitian

\begin{tabular}{|c|c|c|c|c|}
\hline No & Tujuan & Data & Satuan & Sumber data \\
\hline \multirow[t]{11}{*}{1.} & $\begin{array}{l}\text { Mengetahui } \\
\text { kelayakan } \\
\text { usaha }\end{array}$ & $\begin{array}{l}\text { - Jumlah hasil } \\
\text { tangkapan per } \\
\text { jenis ikan }\end{array}$ & $\mathrm{Kg}$ & Wawancara \\
\hline & $\begin{array}{l}\text { perikanan } \\
\text { tangkap }\end{array}$ & $\begin{array}{l}\text { - Harga jual } \\
\text { ikan }\end{array}$ & $\mathrm{Rp}$ & Wawancara \\
\hline & & - Solar & $\mathrm{Rp}$ & Wawancara \\
\hline & & - Konsumsi & $\mathrm{Rp}$ & Wawancara \\
\hline & & $\begin{array}{l}\text { - Investasi } \\
\text { kapal }\end{array}$ & $\mathrm{Rp}$ & Wawancara \\
\hline & & $\begin{array}{l}\text { - Investasi } \\
\text { mesin }\end{array}$ & $\mathrm{Rp}$ & Wawancara \\
\hline & & $\begin{array}{l}\text { - Investasi alat } \\
\text { tangkap }\end{array}$ & $\mathrm{Rp}$ & Wawancara \\
\hline & & $\begin{array}{l}\text { - Penyusutan } \\
\text { kapal }\end{array}$ & $\mathrm{Rp}$ & Wawancara \\
\hline & & $\begin{array}{l}\text { - Penyusutan } \\
\text { mesin }\end{array}$ & $\mathrm{Rp}$ & Wawancara \\
\hline & & $\begin{array}{l}\text { - Penyusutan } \\
\text { alat tangkap }\end{array}$ & $\mathrm{Rp}$ & Wawancara \\
\hline & & $\begin{array}{l}\text { - } \text { Total ongkos } \\
\text { perawatan }\end{array}$ & $\mathrm{Rp}$ & Wawancara \\
\hline
\end{tabular}


Jumlah kapal sampel yang dikumpulkan merupakan jumlah real setiap unit kapal penangkapan ikan pelagis besar yaitu pancing tonda sebanyak 154 unit dan pancing ulur sebanyak 11 unit. Responden nelayan merupakan pemilik dan pekerja pada setiap unit kapal penangkapan ikan pelagis besar dikumpulkan sesuai dengan jumlah kapal sampel.

Analisis usaha merupakan analisis jangka pendek yaitu analisis yang dilakukan untuk mengetahui besarnya keuntungan yang diperoleh dari suatu kegiatan usaha dalam waktu satu tahun. Analisis usaha terdiri atas analisis pendapatan usaha $(\pi)$ dan analisis $\operatorname{BEP}($ break even point). Selain analisis jangka pendek, juga dilakukan analisis investasi berupa analisis NPV (net present value)

1) Analisis pendapatan usaha $(\pi)$

Pendapatan usaha (keuntungan) merupakan selisih antara total penerimaan atau total revenue (TR) dan total biaya atau total cost (TC).Pendapatan usaha dapat dicari dengan menggunakan rumus oleh Wijayanto $d k k$. (2012); Wahyono (2016) sebagai berikut:

Keterangan :

$$
\pi=\mathrm{TR}-\mathrm{TC}
$$

$\mathrm{TR}=$ Total revenue $($ penerimaan total $)$

$\mathrm{TC}=$ Total cost (biaya total operasional)

Dengan kriteria :

$\pi>0$, maka usaha menguntungkan

$\pi=0$, maka usaha impas

$\pi<0$, maka usaha rugi

\section{2) Analisis break even point (BEP)}

Break even point menunjukkan produksi minimum setiap tahun pada tingkat tidak untung dan tidak rugi. Break even point atau analisis titik impas adalah suatu alat analisis yang digunakan untuk mengetahui sampai pada batas mana kegiatan usaha yang dijalankan masih mendatangkan keuntungan. Keadaan titik impas merupakan keadaan dimana penerimaan perusahaan (TR) sama dengan biaya yang ditanggungnya (TC), TR=TC. Break even point dapat dirumuskan menurut Wijayanto $d k k$. (2012); Wahyono (2016) sebagai berikut :

$$
\begin{aligned}
& \operatorname{BEP}(K g)=\frac{\text { Biaya tetap } x \text { Produksi }}{\text { Hasil penjualan-Biaya variabel }} \\
& \operatorname{BEP}(R p)=\frac{\text { Biaya tetap }}{1-\frac{\text { Biaya variabel rata-rata }}{\text { Hasil Penjualan }}}
\end{aligned}
$$

\section{3) Net present value (NPV)}

Net present value digunakan untuk menilai manfaat investasi, yaitu berapa nilai kini (present value) dari manfaat bersih proyek yang dinyatakan dalam rupiah. Proyek dinyatakan layak untuk dilanjutkan apabila NPV $>0$, sedangkan apabila $\mathrm{NPV}<0$, maka investasi dinyatakan tidak menguntungkan yang berarti proyek tersebut tidak layak untuk dilaksanakan. Pada keadaan ini nilai $\mathrm{NPV}=0$ maka berarti pada proyek tersebut hanya kembali modal atau tidak untung dan juga tidak rugi. Rumus yang digunakan untuk menghitung NPV adalah menurut Wahyono (2016) :

$N P V=\sum_{t=1}^{n} \frac{\mathrm{Bt}-\mathrm{Ct}}{(1+\mathrm{i})}$

Keterangan :

$$
\begin{aligned}
& \mathrm{B}=\text { benefit } \\
& \mathrm{C}=\text { cost } \\
& i=\text { discount rate } \\
& \mathrm{t}=\text { periode }
\end{aligned}
$$

\section{HASIL DAN PEMBAHASAN}

\section{Hasil}

\section{a. Pendapatan usaha $(\pi)$}

Tujuan dari analisis pendapatan usaha adalah untuk mengetahui besarnya total pendapatan yang diperoleh dari suatu usaha. Total pendapatan diperoleh dari total penerimaan dikurangi dengan total biaya yang dikeluarkan dalam suatu proses produksi. Adapun hasil analisis pendapatan usaha dapat dilihat pada Tabel 2. Berdasarkan kriteria, maka $\pi>0$ yang berarti usaha perikanan tangkap dengan menggunakan alat tangkap pancing tonda dan pancing ulur adalah usaha yang menguntungkan.

Tabel 2. Hasil analisis pendapatan usaha pancing tonda dan pancing ulur

\begin{tabular}{lrr}
\hline \multicolumn{1}{c}{ Komponen } & $\begin{array}{c}\text { Pancing tonda } \\
(\mathbf{R p})\end{array}$ & \multicolumn{1}{c}{$\begin{array}{c}\text { Pancing ulur } \\
(\mathbf{R p})\end{array}$} \\
\hline Total penerimaan & $463.782 .857,00$ & $130.090 .909,00$ \\
$\begin{array}{l}\text { Biaya } \\
\text { dikeluarkan }\end{array}$ yang & $69.867 .661,00$ & $64.743 .939,00$ \\
Keuntungan $(\pi)$ & $393.915 .196,00$ & $65.346 .970,00$ \\
\hline
\end{tabular}

\section{b. Break event point (BEP)}

Break event point adalah keadaan dimana jumlah penerimaan sama dengan jumlah pengeluaran atau disebut dengan kondisi titip impas. Analisis BEP digunakan untuk mengetahui sampai batasmana 
12 Sri Eka Aguslinaet al.

JURNAL SAINS dan INOVASI PERIKANAN / Journal of Fishery Science and Innovation

Vol. 3, No. 1, 9-13, Januari 2019

usaha pengembangan pancing tonda dan pancing ulur masih memperoleh keuntungan. Adapun hasil analisis pendapatan usaha dapat dilihat pada Tabel 3 .

Tabel 3. Hasil analisis BEP pancing tonda dan pancing ulur

\begin{tabular}{lrr}
\hline Komponen & Pancing tonda & Pancing ulur \\
\hline BEP produksi $(\mathrm{Rp})$ & $\mathrm{Rp} 16.939 .023,00$ & $\mathrm{Rp} 21.634 .039,00$ \\
BEP volume $(\mathrm{Kg})$ & $1.532,42 \mathrm{~kg}$ & $2.721,26 \mathrm{~kg}$ \\
\hline
\end{tabular}

Nilai pada BEP produksi alat tangkap pancing tonda memiliki arti bahwa usaha perikanan alat tangkap pancing tonda akan memberikan keuntungan apabila lebih besar dari Rp. 16.939.023,00. Nilai BEP volume pada usaha perikanan pancing tonda memiliki arti bahwa usaha ini akan menghasilkan keuntungan apabila telah memproduksi ikan lebih dari 1.532,42 $\mathrm{kg}$. Berdasarkan hasil perhitungan bahwa nilai BEP produksi dan BEP volume pada pancing tonda dapat dicapai hanya dalam jangka waktu 13 hari.

Nilai pada BEP produksi perikanan pancing ulur memiliki arti bahwa usaha perikanan tangkap dengan alat tangkap pancing ulur akan memberikan keuntungan apabila lebih besar dari Rp. 21.634.039,00. Hal demikian, pada nilai BEP volume pada usaha alat tangkap pancing ulur mengartikan bahwa usaha ini akan menghasilkan keuntungan apabila telah memproduksi ikan lebih dari 2.721,26 $\mathrm{kg}$. Berdasarkan hasil perhitungan bahwa nilai BEP produksi dan BEP volume pada pancing ulur dapat dicapai hanya dalam jangka waktu 61 hari atau selama 2 bulan.

\section{c. Net present value (NPV)}

Analisis NPV bertujuan untuk mengetahi manfaat investasi untuk setiap usaha. Asumsi yang diperlukan dalam menyusun perhitungan NPV adalah

Analisis yang dilakukan merupakan usaha baru yang akan dikembangkan, dimana usaha yang ada dengan umur kegunaan ditentukan 8 tahun untuk pancing tonda dan 9 tahun untuk pancing ulur, karena nilai investasi yang paling tinggi dan lama adalah kapal; (ii) Harga yang digunakan baik untuk biaya maupun penerimaan adalah konstan selama umur proyek; (iii) Nilai-nilai investasi yang digunakan dalam analisis berdasarkan hasil wawancara berdasarkan tahun 2018; (iv) Hasil tangkapan yang masuk ke dalam perhitungan hanya ikan pelagis besar;

Kapal/perahu dan mesin yang digunakan untuk operasi penangkapan memiliki ukuran relatif sama; (vi) Discount factor pada tahun 2018 sebesar 18\% per tahun yang berlaku pada Bank Rakyat Indonesia
(BRI); dan (vii) tingkat suku bunga pada tahun 2018 sebesar 0,3\% per tahun yang berlaku pada Bank Rakyat Indonesia. Adapun hasil analisis pendapatan usaha dapat dilihat pada Tabel 4 ..

Tabel 4. Hasil analisis NPV pancing tonda dan pancing ulur

\begin{tabular}{lrr}
\hline Komponen & Pancing tonda & Pancing ulur \\
\hline NPV & Rp $601.942 .221,00$ & Rp 215.366.439,00 \\
\hline
\end{tabular}

Nilai NPV pancing tonda mengartikan bahwa nilai saat ini dari keuntungan yang akan diperoleh selama umur proyek 8 tahun di masa yang akan datang adalah Rp. 601.942.221,00. Dari hasil perhitungan tersebut dapat disimpulkan bahwa usaha pengembangan alat tangkap pancing tonda di Kabupaten Wakatobi layak untuk dikembangkan (NPV>0).

NPV pancing ulur berarti bahwa nilai saat ini dari keuntungan yang akan diperoleh selama umur proyek 9 tahun di masa yang akan datang adalah $\mathrm{Rp}$. 215.366.439,00. Hasil perhitungan tersebut menunjukkan bahwa usaha pengembangan alat tangkap pancing ulur di Kabupaten Wakatobi layak untuk dikembangkan (NPV $>0)$.

\section{Pembahasan}

Salah satu harapan dalam pengembangan perikanan tangkap ikan pelagis besar di Kabupaten Wakatobi adalah dapat membantu pengoptimalan usaha perikanan pelagis besar. Oleh karena itu dilakukan analisis kelayakan usaha untuk menilai kelayakan dari alat tangkap yang digunakan dalam perikanan pelagis besar yaitu pancing tonda dan pancing ulur. Berdasarkan hasil perhitungan analisis kelayakan usaha, maka dapat diketahui bahwa pancing tonda dan pancing ulur layak untuk dikembangkan karena semua syarat dalam П, BEP, dan NPV sebagai kriteria kelayakan suatu usaha dapat dipenuhi.

Berdasarkan hasil analisis, walaupun kedua alat tangkap ini memenuhi kriteria kelayakan usaha, tetapi pancing tonda lebih prioritas untuk dikembangkan karena memiliki nilai kriteria usaha yang lebih besar dibandingkan pancing ulur. Dilihat dari pendapatan usaha pancing tonda mencapai Rp. 393.915.196,00 per tahun. Usaha pancing tonda telah mengalami keuntungan, jika nelayan memperoleh hasil tangkapan dengan nilai lebih dari Rp. 16.939.023,00 per tahun dan memproduksi hasil tangkapan lebih banyak dari $1.532,42 \mathrm{~kg}$. Keuntungan tersebut didapatkan hanya 
dalam jangka waktu 13 hari. Nilai NPV sebesar Rp. 601.942.221,00 yang berarti bahwa nilai saat ini dari keuntungan yang akan diperoleh selama umur proyek 8 tahun di masa yang akan datang. Hal ini sesuai dengan penelitian Sudirman (2013); Wijaksono dkk. (2014); Wasahua dan Lukman (2016); bahwa alat tangkap pancing tonda dan pancing ulur merupakan alat tangkap yang layak untuk dikembangkan berdasarkan analisis kelayakan usaha. Dilanjutkan bahwa pancing tonda memiliki nilai kriteria kelayakan usaha yang lebih besar dibandingkan pancing ulur, misalnya pendapatan bersih rata-rata per trip yang didapatkan oleh nelayan pancing tonda sebesar Rp. 2.725.778,27 dibandingkan pancing ulur hanya mampu mendapatkan pendapatan bersih sebesar Rp. 945.731 (Wasahua dan Lukman, 2016).

\section{KESIMPULAN}

Pancing tonda dan pancing ulur yang merupakan plat tagkap ikan pelagis besar yang digunakan di Kabupaten Wakatobi layak untuk dikembangkan karena semua syarat dalam П, BEP, dan NPV sebagai kriteria kelayakan suatu usaha dapat dipenuhi.

\section{DAFTAR PUSTAKA}

Alimina N, Wiryawan B, Monintja DRO, Nurani TW, Taurusman AA. 2015. Comparing different small-scale tuna fishery suppliers: a case study on trolling line and poleand line in Southeast Sulawesi, Indonesia. AACL Bioflux 8(4): 500506.

Alimina N, Wiryawan B, Monintja DRO, Nurani TW, Taurusman AA. 2015. Cedera dan praktek keselamatan kerja pada perikanan tuna skala kecil di perairan selatan Sulawesi Tenggara. Prosiding Simposium Pengelolaan Perikanan Tuna Berkelanjutan; 2014 Des 10-11; Bali, Indonesia. Jakarta : WWF 158-167.

Alimina N, Wiryawan B, Nurani TW, Taurusman AA. 2016. Estimasi tangkapan per unit upaya baku dan proporsi yuwana pada perikanan tuna di Sulawesi Tenggara. Marine Fisheries 7(1): 57-68

Bappeda Wakatobi Badan Perencanaan Pembangunan Daerah Kabupaten Wakatobi. 2016. Rencana pembangunan jangka menengah daerah (RPJMD) Kabupaten Wakatobi tahun 2016 2021. Wangi-Wangi.
DKP Wakatobi Dinas Kelautan dan Perikanan Kabupaten Wakatobi. 2016. Laporan statistik perikanan tangkap. Sulawesi Tenggara

Kementerian Kelautan dan Perikanan. 2016. Peraturan menteri kelautan dan perikanan republik indonesia nomor 71/Permen-KP/2016 tentang jalur penangkapan ikan dan penempatan alat penangkapan ikan di wilayah pengelolaan perikanan negara republik indonesia.

Sudirman. 2013. Pengembangan usaha penangkapan ikan tuna di Kota Sorong Papua Barat. Jurnal Airaka 2: $11-19$.

Wahyono T. 2016. Manajemen bisnis perikanan: manajemen stratejik dan analisis kelayakan. edisi pertama (Cet. 1). Plantaxia: Yogyakarta.

Wasahua J, Lukman E. 2016. Analisis kelayakan finansial perikanan tangkap ikan pelagis besar di Desa Tial Kecamatan Salahutu Kabupaten Maluku Tengah. Jurnal Ilmiah Agribisnis dan Perikanan (agrikan UMMU-Ternate) 9(2): 30-33.

Wijaksono BPN, Mudzakir AK, Pramonowibowo. 2014. Analisis aspek teknis dan finansial alat tangkap tonda di TPI Watukarung Kabupaten Pacitan. Journal of Fisheries Resources Utilization Management and Technology 3(3): 183-189.

Wijayanto D, Mudzakir AK, Haditomo AHC, Huda MN. 2012. Studi kelayakan bisnis perikanan karang, budidaya kerapu dan rumput laut di Kabupaten Flores Timur dan Lembata [Laporan Akhir]. Kerjasama Kementerian Kelautan dan Perikanan Republik Indonesia, Pemerintah Daerah Flores Timur dan Lembata, serta WWF. 